\title{
The Epistemological Aspect of Ibn Al-Haytham's Scientific Thought
}

\author{
Mohd Syahmir Alias, Mohd Shukri Hanapi* \\ Centre for Islamic Development Management Studies (ISDEV), Universiti Sains Malaysia, 11800 Pulau Pinang, Malaysia \\ *Corresponding author: hshukri@usm.my
}

\begin{abstract}
The discussions on epistemology are closely related to the source and methodology of obtaining knowledge. Today's modern scientific methodology which is driven by logical positivism philosophy lay too much importance on data that can be observed by the senses and is rational to the mind. Therefore, it have a few differences from the Islamic epistemological framework which are value driven in process. However, it was said that Ibn al-Haytham is one the earliest Muslim scholars to base his research on scientific methods. The question is how Ibn al-Haytham obtains scientific knowledge? Does it fit into Islamic epistemological framework? Hence, this article intends to identify the epistemological aspects of Ibn al-Haytham's scientific thoughts by using the content analysis method. The findings showed that Ibn al-Haytham's scientific epistemology is based on reflection on the verses of al-Qur'an, belief in God's law (sunnatullah) of nature, observation by the senses, cognitive reasoning, and intuition. Therefore, the source of knowledge pertaining to Ibn alHaytham's scientific thoughts is integrated as what shown in the discussion of Islamic epistemology.
\end{abstract}

Keywords: Ibn al-Haytham; scientific; thought; God's law; epistemology

\begin{abstract}
Abstrak
Perbincangan epistemologi sangat berkait rapat dengan sumber dan perkaedahan memperoleh ilmu pengetahuan. Perkaedahan saintifik moden yang wujud pada hari ini adalah berpandukan falsafah logical-positivism yang mementingkan data yang boleh dicerap oleh deria dan bersifat rasional pada akal sematamata. Oleh itu, ia mempunyai perbezaan dengan kerangka epistemologi Islam yang sarat dengan nilai. Walau bagaimanapun, terdapat pendapat yang mengatakan bahawa Ibn al-Haytham merupakan antara sarjana Muslim terawal mengasaskan kaedah saintifik dalam penyelidikannya. Persoalannya, bagaimanakah Ibn al-Haytham memperoleh ilmu pengetahuan sains? Adakah kaedah beliau sesuai dengan kerangka epistemologi Islam? Oleh yang demikian, makalah ini bertujuan mengenal pasti aspek epistemologi dalam pemikiran saintifik Ibn al-Haytham dengan menggunakan kaedah analisis kandungan. Dapatan menunjukkan bahawa epistemologi saintifik Ibn al-Haytham berasaskan pemahaman ayat-ayat al-Qur'an, pegangan terhadap sunnatullah alam tabii, pemerhatian oleh deria, penaakulan akal dan pengupayaan intuisi. Justeru, sumber Ibn al-Haytham memperoleh ilmu pengetahuan sains adalah bersepadu dengan epistemologi Islam.
\end{abstract}

Kata kunci: Ibn al-Haytham; pemikiran saintifik; sunnatullah; intuis; epistemologi

(C) 2016 Penerbit UTM Press. All rights reserved

\subsection{INTRODUCTION}

The scientific research method is defined as a technique for researching a natural phenomenon in order to obtain new knowledge and to combine or amend previous knowledge (Goldhaber \& Nieto, 2010:940). More specifically, the scientific research method is closely related to the definition of science. Science is a research activity that uses a particular method such as an experimental method that strongly emphasises on accuracy during observations. Next, the outcome of the observation needs elaboration using theories that are understood by the most generalised characteristics (Medawar, 1984).

This method must now be utilised to justify all the fields of knowledge if that field wishes to achieve universality and be accepted by the global community (Selamat Amir, Mohd Murshidi Mohd Noor \& Ahmad Bazli Ahmad Hilmi, 2012:52). From an epistemological aspect, this methodology is based on the logical-positivism philosophy founded by the Vienna Circle (Betz, 2011:32). Literally, epistemology means theory of knowledge. In terms of terminology, it is a branch of philosophy that discusses the characteristics and justifications of knowledge, its limitations, definitions of the forms of knowledge and the ways of obtaining knowledge and its limitations (Ahmad Sunawari Long, 2008:127).

The logical-positivism philosophy overly believes that knowledge must be solely based on the experience of the senses (Mohammed Yusoff Hussain, 2002:85). This shows that they do not recognise the source of knowledge based on divine revelation and inspiration (Muhammad Syukri Salleh, 2001:23). In other words, logical-positivism is a philosophical approach intended to determine the truth with the assumption that objective reality exist out there. Logical-positivists believe that it is the duty of social scientists and natural scientists to explore this reality and collect empirical proof, which are facts that could be verified by the senses (Macionis, 2003:28). 
From a historical perspective, Ibn al-Haytham was a researcher during the helm of Islam who used scientific methods in his research (Omar Khaleefa, 1999:3; Kennedy, Radach \& Pynte, 2000; Gorini, 2003:55; Jim Al-Khalili, 2009). He was one of the pioneer Muslim scholars to implement research by considering all aspects of modern scientific methodology (Ab. Latif Muda \& Rosmawati Ali @ Mat Zain, 2009:327). In fact, during the helm of Islam, scientific research was not considered a secular activity (Mohd Yusof Othman, 2009). This paper intends to determine how the epistemology of Ibn al-Haytham's scientific method is different from that of the conventional scientific method and how it fits into the Islamic epistemological framework. Therefore, in order to answer these emerging questions, this paper has two important objectives. The first is to review the Islamic epistemological framework and the second is to identify the epistemological aspect of Ibn al-Haytham's scientific thoughts.

\subsection{LITERATURE REVIEW}

This literature review contains two important aspects. First is about Ibn al-Haytham's life and work and second is regarding Islamic epistemology.

Ibn al-Haytham's full name is Abu 'Ali al-Hasan Ibn al-Hasan Ibn al-Haytham al-Basri al-Misri (Wahyu Murtiningsih, 2010:17). He was known as "Ptolemaeus Secundus" (the Second Ptolemy) because of his achievements in the field of optics and astronomy, which was equivalent to Ptolemy, the ancient Greek astronomer (Corbin, 1993:149). According to Nazir Ahmad (1969:35) and Steffens (2007:40-41), Ibn al-Haytham came from a middle class family that lived in Basra (a city in Iraq) where he worked as a vizier. However, in order to pursue his studies in the sciences and intellectual writing, he resigned from his work. He next travelled to Ahwaz before residing in Baghdad (Syed Mahadzir Syed Onn, 2005:90). While in Baghdad, the Caliph of the Fatimiyyah Sultanate, Caliph al-Hakim bi-Amrillah, invited him to Egypt. According to al-Qifti (1908), the Caliph invited him because the Caliph thought that Ibn al-Haytham's work in geometry could mitigate flood problems caused by the Nile River by the construction a dam.

Unfortunately, due to the treacherous conditions of the Nile River and the limited availability of technology at that time, he could not pursue his work (Hameed Askari, 1969:73). Sulaiman Fayyad (1998:36) stated that the Caliph then punished Ibn al-Haytham by arresting him in his own home. Hence, because of that, Ibn al-Haytham pretended to be insane so that he could escape imprisonment but he never succeeded. After ten years, the Caliph died and Ibn al-Haytham was set free.

According to Yazid Abdul Manap (2011:148), when Ibn al-Haytham was imprisoned, he continued to study the nature of light. This venture helped him discover the basis of the camera, which is called camera obscura (bayt al-muzlim) and is recorded in his magnum opus, Kitab al-Manazir (Book of Optics). Besides optics, Ibn al-Haytham also studied astronomy. Roshdi Rashed (2007:7-8) stated that Ibn al-Haytham wrote approximately 25 literary works on astronomy. Moreover, he also contributed to the fundamental theory on momentum and inertia (Seyyed Hossein Nasr, 1987:129).

On the other hand, Islamic philosophy is born and breed on certain foundations. These foundations are related to theory or the origins of Islamic knowledge, which is known as Islamic epistemology (Syed Muhammad Naquib Al-Attas, 1995:4; Sidek Baba, 2006:186). Actually, epistemology originated from two Greek words, namely episteme and logos. Episteme means knowledge, meanwhile logos means theory or a study of (Blackburn, 1994123; Muhyar Fanani, 2009:15). Epistemology is the in-depth discussion on the processes that bring about the addition of knowledge (Roziah Sidik, Zulkarnain Mohamed \& Nasruddin Yunos, and 2011:47). This is also known as nazariyyat al-ma 'rifah in Islamic traditions (Murtada Mutahhari, 2011:1; Mohd Radhi Ibrahim, 2003:1).

According to Sidek Baba (2006:186-187) and Hamid Fahmy Zarkasyi (2007), Islamic epistemology consists of two main sources, which are the naql (divine revelation) and 'aql (ijtihad or reasoning on the basis of Qur'an and al-Sunnah). Sources of naql are Qur'an or al-wahy al-matlu (divine revelation that has been read) and al-Sunnah or al-wahy ghayr al-matlu (divine revelation that has not been read). Both are also known as al-adillah al-qat 'iyyah or proof that has legitimacy, which cannot be challenged. Meanwhile, the 'aql source, especially those that have been agreed upon by the al-ijma' and al-qiyas. Both these sources are known as al-adillah al-ijtihadiyyah or views that were formed at after some laborious and intense thinking.

Moreover, there are explicit views that divide Islamic epistemological framework into five sources of knowledge, which are recognized in Islam, such as divine revelation (wahy), inspiration (ilham), intuition, intellect ('aql), and senses (Hassan Langgulung, 1986:19-23; Fadzila Azni Ahmad, 2010: 117 \& 119). However, Sidek Baba (2006:186-187) mentioned that there are four elements, which are the platform or basis of Islamic epistemology. The main element is staunch belief ( $a q i d a h$ ), while the rest of the elements are worship ('ibadah), ethics (akhlaq) and Islamic legislation (syari'ah). Ziaudin Sardar (1990:89) stated that epistemology is the main thrust for any view on life.

\subsection{METHODOLOGY}

The data collection method used in this research was library research. This is an important method for this research because it involves Ibn al-Haytham's thought, which necessitated access to long-term documents, also known as longitudinal data (Bailey, 1982:303). Specifically, the sources for the data in this study were grouped accordingly and detailed into four sections. The group of data from the first and main source was the al-Qur'an and Hadith. The second section was Ibn al-Haytham's autobiography that was edited by an authoritative writer named Ibn Abi Usaybi'ah (1965). The third section was the works of Ibn al-Haytham, among them was his famous work entitled Kitab al-Manazir (Book of Optics). Lastly, the fourth section was systematic studies like thesis and journal articles as well as seminar papers produced by previous researchers.

Since the data was collected from sources such as divine revelations, thesis, books and journals, which are actually archive documents; hence, the data was analysed using the content analysis method. This is in accordance with what Neuman (2011:49) stated about content analysis, which refers to a type of systematic analysis involving communicated documents. Content analysis also implicates the measurement of structure, content and literature sources (Sulaiman Masri, 2005:21). 


\title{
4.0 RESULTS AND DISCUSSION
}

Ibn al-Haytham's scientific epistemology is his main belief when implementing scientific research and determining its methodology. This paper found five epistemological aspects of scientific thoughts of Ibn al-Haytham. The first is reflection on the verses of the al-Qur'an; the second, understanding the nature of God's law (sunnatullah); the third, empirical observation and experimentation; the fourth, logical reasoning and mathematics; and fifth, the capability of intuition.

\section{Reflection on the Verses of the Al-Qur'an}

According to Ab. Halim Tamuri (2011:25), early studies based on divine deliverance have become a guide in carrying out research by Islamic researchers. Moreover, the essence of the al-Qur'an and the Hadith has become factors that develop and encourage scholars in the tradition of previous Islamic intellectualism when seeking knowledge (Chaudhry Abdul Qadir, 1990:25; Ahmad Sunawari Long, 2008:15). This is what happened during Ibn al-Haytham's early education years. During his younger days, he had studied fields related to the alQur'an and Hadith in mosques around Basrah, which functioned as a centre of knowledge for Muslims (Abdul Ghafur Chaudhri, 1969:109-110; Steffens, 2007:25-26).

There are other arguments that support the view that Ibn al-Haytham's scientific epistemology is substantiated by verses from the alQur'an. This is evident in a literary work entitled Maqalah fi Daw' al-Qamar (Commentary on the Light of the Moon). The moon by itself does not produce light as understood by early societies because the moon only reflects the sun's rays (Mat Rofa Ismail, 2006:33). In Maqalah fi Daw' al-Qamar, Ibn al-Haytham begins his article by posting a verse of the al-Qur'an (Abdul Ghafur Chaudhri, 1969:122). The verse is the exhortation of Allah SWT meaning:

\begin{abstract}
"It is He who made the sun a shining light and the moon a derived light and determined for it phases - that you may know the number of years and account [of time]. Allah has not created this except in truth. He details the signs for a people who know..."
\end{abstract}

(Yunus, 10:5)

Ibn al-Haytham (1969) used this article with the intention of explaining in detail about moon light reaching the earth. This is because scientists during his time understood the phenomenon as a reflection of the sun's rays by the moon as in a mirror. Hence, Ibn al-Haytham's research findings, which are complete with arguments based on geometry and a systematic experimental method (Abdelhamid I. Sabra, 1989:xli), reason that sunlight that falls on a specific point on the moon's surface actually lights up the moon. In addition, due to the atomic characteristics of the moon, it allows its reflection to be seen from every direction when observed from earth (Ibn al-Haytham, 1969:214).

This specific explanation shows that the al-Qur'an had successfully inspired Ibn al-Haytham to closely observe and logically deduce all the natural phenomena that are sunnatullah (Abdul Basir Pal, 1969:98) because both the verses (verses from the al-Qur'an and natural phenomenon) are derived from the same source, which is Allah SWT (Khalijah Mohd Salleh, 2011:77). Natural phenomenon is also known as al-ayat al-kawniyyah (Thameem Ushama, 2011), meanwhile the al-Qur'an is known as the al-ayat al-qawliyah. Since both these verses are derived from the Great Creator, there are no contradictions between the two except the interpretations and analysis by researchers who might face limitations.

Understanding the Nature of God's Law (Sunnatullah)

By scrutinizing the verses of the al-Qur'an, Ibn al-Haytham's is confident that the universe is the creation of Allah SWT the Almighty. Hence, according to him, human kind needs to constantly seek the assistance of Allah SWT. This is seen in an excerpt from one of his works, as shown below.

"For all that, we are not free from human turbidity which is in nature; but we must do our best with what we possess of human power. From God we derive support of all things.” (Ibn al-Haytham, 1989:6)

His dependence, as evident in the excerpt above, shows that only Allah SWT has the power to subdue and force His creations to show allegiance to human kind in order for human kind to observe and enjoy its advantages (Muhammed Mumtaz Ali, 1994:88). Moreover, Ibn al-Haytham also believed in the concept of al-hatmiyyat al-ilmiyyat (scientific determinism), which is a concept whereby the natural phenomenon condescends to a harmonious regulation or code otherwise known as the sunnatullah. This regulation or code allows the observation to be carried out repeatedly (Mat Rofa Ismail, 1997:122). The proof on this matter was found in an excerpt from one of his works shown below.

\footnotetext{
"The characterization of the eye by this property is one of the things that show the wisdom of the Artificer, great be His glory, the skilfulness of His work and the successful and skilful manner in which nature has arranged the instruments of sight..." (Ibn al-Haytham, 1989:103)
}

In his research on optics, Ibn al-Haytham (1989:103-104) admitted that the orderliness of the human sight process, including the batting of the eyelids when dust enters the eye, is sunnatullah. Hence, it is clear that natural proclivities that fall back on the laws and regulations set forth by Allah SWT facilitate Ibn al-Haytham to make observations and logical conclusions about the phenomenon. Thus, it is clear that sunnatullah is also the basis for Ibn al-Haytham's scientific epistemology. 


\section{Empirical Observation and Experimentation}

Ibn al-Haytham explained that observation and logical reasoning are the basic elements in his scientific epistemology. This is evident in an excerpt from one of his works:

"I observed that I would not reach the truth except from sight or sensory matters being its origin, and its formation being intellectual matters.” (Ibn Abi Usaybi'ah, 1965:552)

Specifically, the method used by him is known as al-istiqra' wa al-tajribah (the induction and experimental method), which is now called the modern scientific method (Mat Rofa Ismail, 2012b:183). According to Muhammad Saud (1990:69), Shuttleworth (2009) and Mat Rofa Ismail (2012a:124), there are at least four main stages in Ibn al-Haytham's research method. The first stage is about carrying out observations; the second is to build the hypothesis; the third is to carry out the experiments and the fourth is to make the conclusions. These four stages in the methodology segment are paired with the basic elements outlined by Ibn al-Haytham, which are observations and experiments that truly need the senses and secondly, the hypothesis formulation and arguments relevant to the conclusions that stress on the importance of the ability to reason intellectually.

Based on the works of Ibn al-Haytham, there are researches that could be subjected to observations and verifications with experiments. This matter is mentioned in his work Kitab al-Manazir (Book on Optics), which relates to light travelling in a straight line. The experiment to prove that light travels in a straight line is described in detail in Kitab al-Manazir Volume 1 Chapter 3. He obtained the idea from observing dust particles found in a stream of light and clearly visible in a dark room with a hole (Ibn al-Haytham, 1989:13). Thus, based on this research, he had created a model called bayt al-muzlim (camera obscura), which is a model based on the human eye and later replicated in the camera's lens (Mat Rofa Ismail, 2012a:124-125).

In addition, there are researches that could be carried out with only observations. This kind of research was carried out by him, as mentioned in his work on astronomy called Maqalah fi Hay'at al- 'Alam (Commentary on the Configuration of the World). For example, Ibn al-Haytham (1990:172) had mentioned in that paper that consistent observations had shown that Mercury is at a fixed distance from the position of the sun. This shows that Ibn al-Haytham had based his arguments solely on observations because research on out-of-space objects lays emphasis on acute observations (Abdul Ghafur Chaudhri, 1969:114). However, Ibn al-Haytham also admitted the existence of limitations in his scientific methodology. In the introduction to Kitab al-Manazir, he admitted to the weaknesses faced by human senses, as seen in his excerpt below.

"For the truths are obscure, the ends hidden, the doubts manifold, the minds turbid, the reasonings various; the premises are gleaned from senses and the senses (which are our tools) are not immune from error." (Ibn alHaytham, 1989:3)

Hence, in Maqalah fi al-Syukuk 'ala Batlamyus (Commentary on the Doubts in Ptolemy) Ibn al-Haytham related the deficiencies found in scientists and knowledge developed by them to Allah SWT. He clearly mentioned that:

"God however has not preserved the scientist from error and has not safeguarded science from shortcomings and faults." (Pinès, 1986:436)

Through both these excerpts, Ibn al-Haytham explained that the ability of the senses as an important scientific epistemology has its limitations because absolute knowledge only exists in Allah SWT (Muhammed Mumtaz Ali, 1994:49).

\section{Logical Reasoning and Mathematics}

Besides that, the second basic element, which is mental or intellectual reasoning, has its own perspective. Based on Ibn al-Haytham's rational arguments, he cannot escape from relating the physical gap with the metaphysical matters. In Kitab al-Manazir Volume 2 Chapter 3 , he discussed the human faculty of judgement about things that humans have seen before, which have actually been formed in the souls of humans. Hence, the ability to make judgements does not need much energy because it occurs naturally or according to natural tendencies (Ibn al-Haytham, 1989:131-138).

Ibn al-Haytham emphasised in his principle that every scientific research needs a combination of mathematics and the physical phenomenon (Muhammad Saud, 1990:18; Mohaini Mohamed, 2000:55; Abdi Omar Shuriye, 2011:62). This is clearly stated in the corpus on optics, Kitab al-Manazir as found in the excerpt below.

"Our subject is obscure and the way leading to knowledge of its nature difficult; moreover, our inquiry requires a combination of the natural and the mathematical sciences." (Ibn al-Haytham, 1989:4)

According to Ibn al-Haytham, mathematics is a tool for verifying (burhan) a phenomenon that is observed. In Maqalah fi al-Tahlil wa al-Tarkib (Commentary on Analysis and Synthesis), Ibn al-Haytham stated that mathematics is a more general method of analysis and it is very useful for solving other problems as well (Mahmoud al-Deek, 2004). This statement is in line with the views of Islamic scholars such as Imam al-Syafi'i (767-820), who stated that learning mathematics could rejuvenate the human mind (Abdul Rahman Abdullah, 2010:40).

According to a majority of Muslim scholars, mathematics is the intermediary between physics and the metaphysics (Mat Rofa Ismail, 1997:84). As mentioned by a group of Muslim philosophers (Ikhwan al-Safa') mathematics is a means for explaining the elements of physics. However, the objective of physics is to ascend to metaphysical science, which is the core of knowledge (Mat Rofa Ismail, 1997:85). Specifically, this can be seen in the case study about the phenomenon of moonlight by Ibn al-Haytham. He used mathematical evidence besides observations of the moon, which eventually substantiated the tawhid (oneness of God). Therefore, it is clear that mathematical reasoning is an important epistemology in science and strongly emphasised by Ibn al-Haytham. 


\section{The Capability of Intuition}

Ibn al-Haytham did not neglect matters occurring due to natural tendencies or impulses in his scientific thinking. In his autobiography, he quoted the words of Galen pertaining to intuition or inspiration. Galen's words gave an impression that the existence of intuition or inspiration conferred by Allah SWT is the source of his wisdom in seeking and delivering knowledge. The excerpt is presented below.

"I don't know how it was possible for me, since my youth to speak wisely. You may say it was by wondrous coincidence or you may say it was by inspiration from God...” (Ibn Abi Usaybi‘ah, 1965:552)

This had influenced the thinking of Ibn al-Haytham and is evident in his success in integrating the elements of intuition and matters mentioned in his discussions about psychoanalysis (Gonzalez, 2002:7; Nader El-Bizri, 2005:195-196). According to Osman Bakar (1991:28), the momentum concept (quwwah al-harakah) introduced by Ibn al-Haytham is the achievement attained from the spurt in creative thinking, which was then proved through experiments.

Moreover, in Maqalah fi al-Tahlil wa al-Tarkib, Ibn al-Haytham was aware that an analysis is not just solving algorithms that could be applied automatically by using mathematical formulas but an analysis lays importance in the capability of intuition (Mahmoud al-Deek, 2004). Hence, intuition is an important scientific epistemology for him in order to logically reason in a more in-depth fashion.

\subsection{CONCLUSION}

Therefore, it can be concluded that this paper has found five important scientific epistemologies attributed to Ibn al-Haytham, which are different from the views of logical-positivists. First, the verses in the al-Qur'an function as a reflection of his research. Second, the sunnatullah as his basis in understanding nature. Third, the senses that are used in observations and to carry out experiments in his research. Fourth, the logical and mathematical reasoning used to verify a phenomenon that he observed. Fifth, the ability of intuition to foster creative thinking.

Furthermore, he admitted the existence of limitations inherent in the use of the senses and cognition to obtain ultimate knowledge. Next, Ibn al-Haytham laid his trust on the elements of human nature (fitrah), such as intuition and nature's sunnatullah, to be a part of carrying out scientific research. Hence, the source of knowledge pertaining to Ibn al-Haytham's scientific research is integrated as shown in the discussions on Islamic epistemology.

\section{References}

Ab. Halim Tamuri (2011). "Al-Qur'an dan Alam sebagai Sumber Ilmu Sains dalam Pendidikan”, in Khalijah Mohd Salleh (Ed.). Pendidikan Sains Berteraskan Tauhid. Bangi, Institut Islam Hadhari, Universiti Kebangsaan Malaysia, Selangor.

Ab. Latif Muda \& Rosmawati Ali @ Mat Zin (2009). Pengantar Ilmu Mantik. Pustaka Salam Sdn. Bhd, Kuala Lumpur.

Abdelhamid I. Sabra (1989). The Optics of Ibn al-Haytham, Book I-III: On Direct Vision (Part II: Introduction, Commentary, Glossaries, Concordance, Indices). Warburg Institute, University of London, London.

Abdi Omar Shuriye (2011). "Islamic Position on Physics with Reference to Ibn al-Haytham". International Journal of Applied Science and Technology, 1(2), 59-64.

Abdul Basir Pal (1969). "Ibn al-Haitham", in Hakim Mohammad Said (Ed.). Ibn al-Haitham: Proceedings of the Celebrations of 1000 ${ }^{\text {th }}$ Anniversary Held under the Auspices of Hamdard National Foundation. Hamdard Academy, Karachi.

Abdul Ghafur Chaudhri (1969). "Ibn al-Haitham: The Educational and Scientific Importance of His Writing", in Hakim Mohammad Said (Ed.). Ibn al-Haitham: Proceedings of the Celebrations of $1000^{\text {th }}$ Anniversary Held under the Auspices of Hamdard National Foundation. Hamdard Academy, Karachi.

Abdul Rahman Abdullah (2010). Wacana Falsafah Sains: Sejarah dan Pemikiran. Centre for Islamic Development Management Studies (ISDEV), Universiti Sains Malaysia, Penang, Malaysia.

Ahmad Sunawari Long (2008). Sejarah Falsafah. Edisi Kedua. Universiti Kebangsaan Malaysia Press, Selangor.

Al-Qifti, 'Ali Ibn Yusuf (1908). Kitab Akhbar al- 'Ulama' bi Akhbar al-Hukama'. Dar al-Kutub al-Ilmiyah, Beirut, Lubnan.

Bailey, K.D. (1982). Methods of Social Research. Second Edition. The Free Press, New York.

Betz, F. (2011). Managing Science: Methodology and Organization of Research. Springer Science+Bussiness Media, New York.

Blackburn, S. (1994). The Oxford Dictionary of Philosophy. Oxford University Press, Oxford.

Chaudhry Abdul Qadir (1990). Philosophy and Science in the Islamic World. Routledge, London.

Corbin, H. (1993). History of Islamic Philosophy. Institute of Ismaili Studies, London.

Fadzila Azni Ahmad (2010). Kaedah Pengurusan Institusi-institusi Pembangunan Berteraskan Islam di Malaysia. UiTM Press, Universiti Teknologi MARA (UPENA), Selangor.

Goldhaber, A.S. \& Nieto M.M. (2010). "Photon and Graviton Mass Limits". Review of Modern Physics, 82, 939.

Gonzalez, V. (2002). Universality and Modernity of Ibn al-Haytham's Thought and Science. The Institute of Ismaili Studies, London.

Gorini, R. (2003). "Al-Haytham the Man of Experience: First Steps in the Science of Vision”. Journal of the International Society for the History of Islamic Medicine, 2(4), 53-55

Hameed Askari (1969). "Ibn al-Haitham: The Greatest Muslim Physicist", in Hakim Mohammad Said (Ed.). Ibn al-Haitham: Proceedings of the Celebrations of $1000^{\text {th }}$ Anniversary Held under the Auspices of Hamdard National Foundation. Hamdard Academy, Karachi.

Hamid Fahmy Zarkasyi (2007). Islam Sebagai Pandangan Hidup. Accessed on May 10 ${ }^{\text {th }}$ 2010, from http://idrusali85.wordpress.com/2007/07/09/islam-sebagai pandangan-hidup/.

Hassan Langgulung (1986). Pengenalan Tamadun Islam dalam Pendidikan. Dewan Bahasa dan Pustaka, Kuala Lumpur.

Ibn Abi Usaybi'ah, Ahmad ibn Qasim (1965). 'Uyun al-Anba' fi Tabaqat al-Atibba'. Beirut, Dar Maktabah al-Hayah, Lubnan.

Ibn al-Haytham, al-Hasan ibn al-Hasan (1969). The Light of the Moon, tranls. Abdul Ghafur Chaudri, in Hakim Mohammad Said (Ed.). Ibn al-Haitham: Proceedings of the Celebrations of $1000^{\text {th }}$ Anniversary Held under the Auspices of Hamdard National Foundation. Hamdard Academy, Karachi, Pakistan.

Ibn al-Haytham, al-Hasan Ibn al-Hasan. (1989). The Optics of Ibn al-Haytham, Book I-III: On Direct Vision, trans. Abdelhamid I. Sabra. Warburg Institute, University of London, London.

Ibn al-Haytham, al-Hasan Ibn al-Hasan. (1990). On the Configuration of the World, trans. Langermann, Y. T. Garland Publishing, New York.

Jim Al-Khalili (2009). The First 'True Scientist'. Accessed on January 30 ${ }^{\text {th }}$ 2013, from http://news.bbc.co.uk/go/pr/fr/-/2/hi/science/nature/7810846.stm.

Kennedy, A., Radach, R., Heller, D. \& Pynte, J. (2000). Reading as a Perceptual Process. Elsevier Science Ltd, Oxford.

Khalijah Mohd Salleh (2011). Pendidikan Sains Berteraskan Tauhid. Institut Islam Hadhari, Universiti Kebangsaan Malaysia, Selangor.

Macionis, J. J. (2003). Sociology. $9^{\text {th }}$ Edition. Prentice Hall, New Jersey. 
Mahmoud al-Deek (2004). "Ibn al-Haitham: Master of Optics, Mathematics, Physics and Medicine", Al-Shindagah, 61. Accessed on August 15 th 2013 from http://www.alshindagah.com/novdec2004/ibn.html.

Mat Rofa Ismail (1997). Mantik dalam Babak Pemikiran Ilmiah Tamadun Manusia. Dewan Bahasa dan Pustaka, Kuala Lumpur.

Mat Rofa Ismail (2006). Falsafah Sains Pendekatan Kualitatif. Dewan Bahasa dan Pustaka, Kuala Lumpur.

Mat Rofa Ismail (2012a). "Penguasaan Ilmu Mantik dan Matematik sebagai Tuntutan Agama: Memanfaatkan Sejarah Keilmuan Islam", in Azrina Sobian (Ed.), Membina Kekuatan Sains di Malaysia. Penerbit Institut Kefahaman Islam Malaysia, Kuala Lumpur.

Mat Rofa Ismail (2012b). "Perluasan Domain Sains: Ke Arah Kajian Sains yang Mengasyikkan", in Azrina Sobian (Ed.), Membina Kekuatan Sains di Malaysia. Penerbit Institut Kefahaman Islam Malaysia, Kuala Lumpur.

Medawar, P. (1984). The Limits of Science. Oxford University Press, New York.

Mohaini Mohamed (2000). Great Muslim Mathematicians. Penerbit Universiti Teknologi Malaysia, Johor.

Mohammed Yusoff Hussain (2002). Pengenalan kepada Sejarah Falsafah Barat Moden. Karisma Publications Sdn. Bhd, Selangor.

Mohd Radhi Ibrahim (2003). "Epistemologi: Satu Tinjauan Menurut Perspektif Islam”, in Mohd Radhi Ibrahim et al. (Ed.), Intelektualisme dan Da ‘wah Masa Kini. Fakulti Kepimpinan dan Pengurusan, Kolej Universiti Islam Malaysia, Kuala Lumpur,

Mohd Shukri Hanapi \& Mohd Syahmir Alias (2015). "The Scientific Research Mould Based on Fardu 'Ayn: A Study from Ibn al-Haytham's Perspective", Social Sciences and Humanities Journal, 10(10), 13-26.

Mohd Syahmir Alias (2014). "Tasawur Pemikiran Saintifik Ibn al-Haytham", Sains Humanika, 2(1), 179-187.

Mohd Yusof Othman (2009). Sains, Masyarakat dan Agama. Utusan Publications \& Distributors, Kuala Lumpur.

Muhammad Saud (1990). The Scientific Method of Ibn al-Haytham. Islamic Research Institute, Islamabad.

Muhammad Syukri Salleh (2001). "Konsep dan Perkaedahan Pengurusan Pembangunan Berteraskan Islam". Pemikir, 26,1 -47.

Muhammed Mumtaz Ali (1994). Islamic and Western Philosophy of Knowledge: Contemporary Methodological Issues. Pelanduk Publications, Selangor.

Muhyar Fanani (2009). Ilmu Ushul Fiqh di Mata Filsafat Ilmu. Walisongo Press, Semarang.

Murtada Mutahhari (2011). The Theory of Knowledge an Islamic Perspective (Mas'aleh-ye Sbinakbt), trans. Mansoor Limba. Institute for Humanities and Cultural Studies (IHCS) \& Ahlul Bayt University, Tehran.

Nader El-Bizri (2005). “A Philosophical Perspective of Alhazen’s Optics”, Arabic Sciences and Philosophy, 15, 189-218.

Nazir Ahmad (1969). "Ibn al-Haitham: His Life and Work", in Hakim Mohammad Said (Ed.). Ibn al-Haitham: Proceedings of the Celebrations of 1000 th Anniversary Held under the Auspices of Hamdard National Foundation. Hamdard Academy, Karachi.

Neuman, W.L. (2011). Social Research Methods, Qualitative and Quantitative Approaches. Seventh Edition. Pearson Education, Boston.

Omar Khaleefa (1999). "Who is the Founder of Psychophysics and Experimental Psychology". The American Journal of Islamic Social Sciences, 16(2), 1-26.

Osman Bakar (1991). Tawhid and Science: Essays on the History and Philosophy of Islamic Science. Secretariat for Islamic Philosophy and Science, Pulau Pinang.

Pinès, S. (1986). The Collected Works of Shlomo Pines Volume II. The Magnes Press The Hebrew University, Jerusalem.

Roshdi Rashed (2007). "The Celestial Kinematics of Ibn al-Haytham". Arabic Sciences and Philosophy, (17), 7-55.

Roziah Sidik, Zulkarnain Mohamed \& Nasruddin Yunos (2011). Pengajian Islam. Edisi Kedua. Oxford Fajar Sdn. Bhd., Shah Alam, Selangor.

Selamat Amir, Mohd Murshidi Mohd Noor \& Ahmad Bazli Ahmad Hilmi (2012). "Aplikasi Elemen Saintifik dalam Tafsir al-Qur'an: Satu Pengamatan Awal Terhadap Manhaj Zaghlul el-Najjar dalam Tafsir al-Ayah al-Kawniyyah fi al-Qur'an al-Karim”. Al-Bayan Journal of Qur'an and Hadith Studies, 10(2), 49-68.

Seyyed Hossein Nasr (1987). Science and Civilisation in Islam. Second Edition. Harvard University Press, United Kingdom.

Shuttleworth, M. (2009). Who Invented the Scientific Method? Accessed on February $4^{\text {th }} 2013$ from http://explorable.com/who-invented-the-scientific-method.

Sidek Baba (2006). Pendidikan Rabbani. Karya Bestari Sdn. Bhd., Selangor.

Steffens, B. (2007). Ibn al-Haytham: First Scientist. Morgan Reynolds Publications, Greensboro, N. C.

Sulaiman Fayyad (1998). Ibnu'l Haitham: Pakar Optometris, trans. Abdul Karim Mustafa. Dewan Bahasa dan Pustaka, Kuala Lumpur.

Sulaiman Masri (2005). Kaedah Penyelidikan dan Panduan Penulisan: Esei, Proposal. Tesis Edisi Baru. Utusan Publications \& Distributors, Kuala Lumpur.

Syed Mahadzir Syed Onn (2005). Siri Pengetahuan Islam: Pendidikan Islam. Penerbitan PCT, Selangor.

Syed Muhammad Naquib Al-Attas (1995). Prolegomena to the Metaphysics of Islam. International Institute of Islamic Thought and Civilization, Kuala Lumpur.

Thameem Ushama (2011). "The Need for Contemporary Understanding of the Qur'an: Considering the Scientific Method (al-Manhaj al-'Ilmi)". Revelation and Science, 1(3), 35-49.

Wahyu Murtiningsih (2010). 99 Ilmuwan Muslim Perintis Sains Moden, trans. Nurul Hanim Abdullah. Al-Hidayah House of Publisher, Selangor.

Yazid Abdul Manap (2011). Menerokai Kegemilangan Saintis Islam. Grup Buku Karangkraf, Selangor.

Ziaudin Sardar (1990). Masa Hadapan Islam (Islamic Future: The Shape of Ideas to Come), trans. Mohd Siden Ahmad Ishak. Dewan Bahasa dan Pustaka, Kuala Lumpur. 